\title{
Genetic diversity and chromosome complement of Galictis cuja (Molina, 1782) (Carnivora: Mustelidae) with comments about its role as parasite hosts Diversidade genética e complemento cromossômico de Galictis cuja (Mustelidae), com comentários sobre seu papel como hospedeiro de parasitas
}

\author{
Júlia Bontempo' | Cecília Bueno" (1) | Paulo Sérgio D’Andrea III (1) | Cibele Rodrigues Bonvicino ${ }^{\text {IV }}$ \\ 'Instituto Federal de Educação, Ciência e Tecnologia do Rio de Janeiro. Rio de Janeiro, Rio de Janeiro, Brasil \\ "Universidade Veiga de Almeida. Rio de Janeiro, Rio de Janeiro, Brasil \\ IIIInstituto Oswaldo Cruz. Fundação Oswaldo. Rio de Janeiro, Rio de Janeiro, Brasil \\ IVInstituto Nacional de Câncer. Rio de Janeiro, Rio de Janeiro, Brasil
}

\begin{abstract}
The distribution of Galictis cuja encompasses several countries of South America, including Brazil, where it inhabits the Atlantic Forest, part of Caatinga and part of Cerrado biomes. Herein we analyzed G. cuja specimens from localities in the Brazilian states of Rio de Janeiro, Minas Gerais, and Bahia, and the Distrito Federal, mainly roadkilled animals. The genetic diversity was estimated based on DNA sequence data of the mitochondrial gene cytochrome $b(m t-c y b)$. Analysis of $m t-$ cyb identified high haplotypic diversity, albeit with low nucleotide diversity, suggesting that this population is in expansion and confirming the presence of gene flow. The karyotypes of two Galictis cuja specimens were described as $2 n=38$ and $\mathrm{FNa}=66$. Our data showed that $\mathrm{G}$. cuja is frequent in the investigated areas of Atlantic Forest biome, being a common roadkill mammal. Our data suggest that $G$. cuja may play a role as a spreader of zoonotic parasites.
\end{abstract}

Keywords: Lesser grison. Cytochrome b. Karyotype. Geographic distribution. Helminths.

Resumo: A distribuição de Galictis cuja abrange vários países da América do Sul, incluindo o Brasil, onde habita a Mata Atlântica, parte da Caatinga e parte do Cerrado. Aqui, analisamos espécimes de G. cuja de localidades nos estados brasileiros do Rio de Janeiro, Minas Gerais, Bahia e no Distrito Federal, a maioria deles encontrada atropelada em rodovias. A diversidade genética foi estimada com base em sequências de DNA do gene mitocondrial citocromo b (mt-cyb). A análise do $m t$ cyb identificou alta diversidade haplotípica, embora com baixa diversidade de nucleotídeos, sugerindo que a população está em expansão e confirmando a presença de fluxo gênico. $\bigcirc$ cariótipo de dois espécimes de Galictis cuja mostrou que $2 \mathrm{n}=38$ e $\mathrm{FNa}=66$. Nossos dados mostraram que G. cuja é frequente nas áreas de Mata Atlântica investigadas, sendo um mamífero comumente atropelado nas rodovias. Eles sugerem que G. cuja tem um papel como disseminador de parasitas zoonóticos.

Palavras-chave: Furão. Citocromo b. Cariótipo. Distribuição geográfica. Helmintos.

BONTEMPO, J., C. BUENO, P. S. D'ANDREA \& C. R. BONVICINO, 2020. Genetic diversity and chromosome complement of Galictis cuja (Molina, 1782) (Carnivora: Mustelidae) with comments about its role as parasite hosts. Boletim do Museu Paraense Emílio Goeldi. Ciências Naturais 15(3): 717-726. DOI: http://doi.org/10.46357/bcnaturais.v15i3.199.

Autora para correspondência: Cibele Rodrigues Bonvicino. Instituto Nacional de Câncer. Divisão de Genética. CPQ. Rio de Janeiro, RJ, Brasil. CEP 20231-050 (cibele.bonvicino@gmail.com).

Recebido em 16/10/2019

Aprovado em 21/09/2020

Responsabilidade editorial: Alexandra Maria Ramos Bezerra
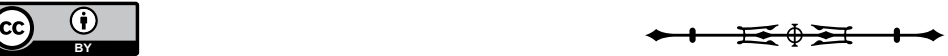


\section{INTRODUCTION}

Galictis Bell, 1826 is a genus of the order Carnivora belonging to the family Mustelidae including two extant recognized species, the greater grison, Galictis vittata (Schreber, 1776) and the lesser grison, Galictis cuja (Molina, 1782). The distribution of $G$. cuja encompasses several countries of South America, including Brazil, where it inhabits the Atlantic Forest, part of Caatinga and part of Cerrado biomes (Bornholdt et al., 2013).

Phylogenetic reconstructions within the Carnivora were extensively carried out (e.g., Flynn \& Nedbal, 1998; Flynn et al., 2005; Eizirik et al., 2010; Koepfli et al., 2007) as well as within the mustelids (e.g., Koepfli \& Wayne, 2003; Koepfli et al., 2008; Sato et al., 2012), showing the monophyly of Galictis (Bornholdt et al., 2013). In contrast, phylogeographic studies in Galictis are less common (Bornholdt et al., 2013). Despite extensive studies of the chromosomal complement of species of the order Carnivora (Franco-de-Sá et al., 2007; Freitas et al., 1982; Kurose et al., 2000), there is a single karyotype description of Galictis cuja only published in a PhD thesis (Barbosa, 2013). Furthermore, this widespread genus has been observed to be infected by several etiological agents of zoonoses as: trypanosomiasis (Ferriolli \& Barretto, 1969; Tremori, 2018), leishmaniasis (Melo, 2008), Toxoplasma gondii (Nicolle \& Manceaux, 1908) (Torres-Castro et al., 2019), zoonotic giant kidney worm Dioctophyme renale (Goeze, 1782) (Barros et al., 1990; Zabottet al., 2012), nematodeosis (Vieira, F.et al., 2012), and a domestic dog strain of Canine Distemper virus (CDV, genus Morbilivirus), that can be transmitted by free-ranging dogs (Megid et al., 2013). The aims of this study are describing the karyotype of Galictis cuja from Southeastern Brazil, investigating the genetic diversity using the mitochondrial gene cytochrome b (mt-cyb) as a marker, and discuss its role as a spreader of zoonotic parasites.

\section{MATERIAL AND METHODS}

We collected 55 specimens of $G$. cuja; mainly roadkilled animals. Thirty-nine specimens were roadkilled in the
BR-040 between 2007 and 2017, three in the RJ-122 in 2018, and 11 were live trapped in rural peridomicile and small fragment borders in Atlantic Forest of Rio de Janeiro and Minas Gerais state (Figure 1). In the Cerrado biome one roadkilled specimen was collected in Distrito Federal. For understanding the extant and ancient distribution of G. cuja, we added the locality of a Pleistocene fossil from Aurora do Tocantins, in Tocantins state (Rodrigues et al., 2015) in the map of Figure 1. Voucher specimens were deposited in the mammal collections of Museu Nacional, UFRJ (MN) and Laboratório de Biologia e Parasitologia de Mamíferos Reservatórios Silvestres (LBCE), Instituto Oswaldo Cruz/ Fundação Oswaldo Cruz (IOC/FIOCRUZ), Rio de Janeiro state, and in Universidade Federal da Paraíba (UFPB), João Pessoa, Paraíba state, Brazil (Appendix 1). The sample were stored at scientific tissue collection of the Laboratório de Biologia e Parasitologia de Mamíferos Resenvatórios Silvestres, IOC/FIOCRUZ, and in the Ecology Laboratory, Universidade Veiga de Almeida, Rio de Janeiro state, Brazil (Appendix 1). Samples of CB and CRB 3283 in Appendix 1 refer to field numbers of Cecilia Bueno (CB) and Cibele R. Bonvicino (CRB) and are only tissue samples, without a voucher.

One specimen of Galictis cuja from Sumidouro (LBCE6437), and one from Teresópolis (LBCE7963), Rio de Janeiro state, were karyotyped. Chromosome preparations were obtained following short cultures of bone marrow tissue (Andrade \& Bonvicino, 2003). Only Giemsa staining coloration was carried out. Chromosomes were ordered according to morphology and decreasing size, with fundamental numbers ( $\mathrm{FNa}$ ) referring to the autosome complement (Levan et al., 1964).

DNA was isolated from liver and muscle samples preserved in ethanol following a phenol-chloroform protocol (Sambrook et al., 1989). The $m t$-cytb sequence was amplified in 28 samples (Appendix 1) with primers "Carnivora Forward" and "Carnivora Reverse" (Ledje \& Arnason, 1996), following a pre-denaturation step at $94{ }^{\circ} \mathrm{C}$ for 2 min following by 35 subsequent cycles with denaturation at $94{ }^{\circ} \mathrm{C}$ for $30 \mathrm{sec}$ and annealing at

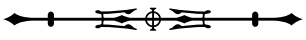




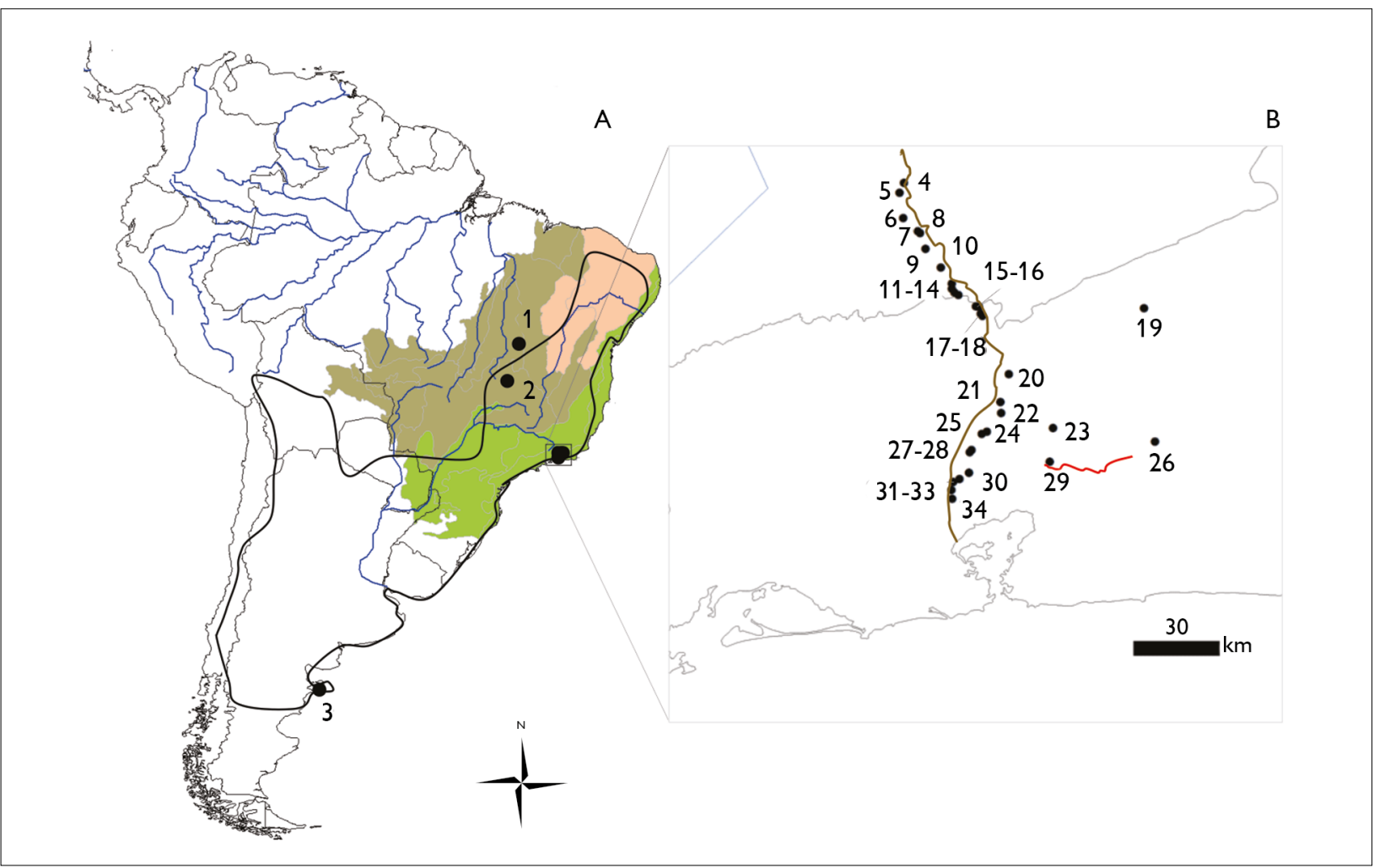

Figure 1. A) South America map showing Atlantic forest (green), Caatinga (salmon), and Cerrado (olive), the current geographic distribution of Galictis cuja (black line), the localities of analyzed specimens (as referred in Table 1 and Appendix 1) and locality 1 of the fossil (Rodrigues et al., 2015); B) the region of BR-040 (in brown) and RJ-122 (line red) highways was amplified for better visualization of collection points.

$54{ }^{\circ} \mathrm{C}$ for $30 \mathrm{sec}$, and extension at $72{ }^{\circ} \mathrm{C}$ for $45 \mathrm{sec}$, and final extension of $72{ }^{\circ} \mathrm{C}$ for $5 \mathrm{~min}$. Amplified products were purified with Gel Band Purification Kit (GE Healthcare), and labelling was carried out using the same primers in addition to the internal primers SOT - In1 (5'-TTRTTRGATCCTGTTTCTTG-3' - Cassensetal., 2000) and SOT - In2 (5'-TGAGGACAAATATCATTTTGAG-3' Cassens et al., 2000). Reactions were run in an ABI3130xl (Applied Biosystems ${ }^{\mathrm{TM}}$ ) platform. Electropherograms were manually checked using CHROMAS PRO 1.41 (Technelysium Pty Ltd). The complete $m t-c y b$ was amplified for all samples, but the different sequenced size was obtained (Table 1). Each sequence was aligned manually with MEGA 7 (Tamura et al., 2013) and a concatenated matrix was manually constructed. The most appropriate nucleotide substitution model for phylogenetic reconstructions was selected using MEGA 7.0. Maximum likelihood (ML) reconstructions were carried with MEGA 7.0, and branch support was calculated using bootstrap. We also used sequences available in GenBank for $G$. cuja (KT626650, AB564025, EF987754) and G. vittata (AF498155). We used as outgroup two species of genera considered as closely related to Galictis (Koepfli et al., 2008; Wolsan \& Sato, 2010), Ictonyx striatus (Perry, 1810) (AF498156.1) and Poecilogale albinucha (Gray, 1864) (EF472349.1). Kimura two-parameters genetic distance estimates were calculated with Mega 7.0.

Network v.4.5.1.6 (Fluxus, s. d.) was used for reconstructing a Median-Joining (MJ) network (Bandelt et al., 1999) based on variable sites and excluding sites containing missing $m t-c y t b$ data to evaluate population structure and geographic distribution patterns. 
Table 1. Samples of Galictis cuja sequenced in this study, with GenBank accession numbers (GenBank), field or scientific collection numbers (voucher), localities (Loc), haplotype $(\mathrm{H})$, number of sequenced base pairs (pb), and source. See Appendix 1 for localities (Loc) of collecting specimens. The number after the GenBank accession number refers to the year the sample was collected.

\begin{tabular}{|c|c|c|c|c|c|}
\hline GenBank/year & Voucher & Loc & $\mathrm{H}$ & $\mathrm{pb}$ & Source \\
\hline MT537199/unknown & CB118 & 10 & $\mathrm{H} 1$ & 1.122 & Present study \\
\hline MT537200/2011 & MN79404 & 10 & $\mathrm{H} 1$ & 1.140 & Present study \\
\hline MT537201/2010 & MN79247 & 16 & $\mathrm{H} 2$ & 1.133 & Present study \\
\hline MT537202/2003 & LBCE5276 & 19 & $\mathrm{H} 2$ & 1.140 & Present study \\
\hline MT537203/2004 & LBCE6587 & 19 & $\mathrm{H} 2$ & 1.140 & Present study \\
\hline MT537204/2004 & LBCE6619 & 19 & $\mathrm{H} 2$ & 1.140 & Present study \\
\hline MT537205/2010 & MN79294 & 16 & $\mathrm{H} 3$ & 1.118 & Present study \\
\hline MT537206/2004 & LBCE6437 & 19 & $\mathrm{H} 3$ & 1.140 & Present study \\
\hline MT537207/unknown & LBCE7241 & 19 & $\mathrm{H} 3$ & 1.084 & Present study \\
\hline MT537208/2011 & MN79358 & 6 & $\mathrm{H} 4$ & 1.140 & Present study \\
\hline MT537209/2011 & MN79407 & 11 & $\mathrm{H} 4$ & 1.140 & Present study \\
\hline MT537210/2015 & CB991 & 9 & $\mathrm{H} 4$ & 1.140 & Present study \\
\hline MT537211/2012 & MN79445 & 8 & $\mathrm{H} 5$ & 1.085 & Present study \\
\hline MT537213/2012 & MN79501 & 30 & $\mathrm{H} 6$ & 1.140 & Present study \\
\hline MT537214/2013 & MN79550 & 30 & $\mathrm{H} 6$ & 1.126 & Present study \\
\hline MT537212/2016 & CB1089 & 12 & $\mathrm{H} 6$ & 1.140 & Present study \\
\hline MT537215/2014 & MN83564 & 13 & $\mathrm{H} 7$ & 1.126 & Present study \\
\hline MT537218/2011 & MN79363 & 9 & $\mathrm{H} 8$ & 1.067 & Present study \\
\hline MT537227/2015 & MN83597 & 5 & $\mathrm{H} 8$ & 601 & Present study \\
\hline MT537216/2016 & CB1012 & 7 & $\mathrm{H} 8$ & 1.140 & Present study \\
\hline MT537217/2016 & CB1185 & 21 & $\mathrm{H} 9$ & 1.118 & Present study \\
\hline MT537220/2005 & LBCE7780 & 19 & $\mathrm{H} 9$ & 1.126 & Present study \\
\hline MT537221/2006 & LBCE7949 & 23 & $\mathrm{H} 9$ & 1.140 & Present study \\
\hline MT537222/2006 & LBCE7956 & 23 & $\mathrm{H} 9$ & 1.140 & Present study \\
\hline MT537223/2006 & LBCE7963 & 23 & $\mathrm{H} 9$ & 1.140 & Present study \\
\hline MT537224/2006 & LBCE7969 & 23 & $\mathrm{H} 9$ & 1.140 & Present study \\
\hline KT626650/unknown & Unknown & - & $\mathrm{H} 9$ & 1.140 & GenBank, unpublished \\
\hline MT537225/unknown & CRB3283 & 2 & $\mathrm{H} 10$ & 1.140 & Present study \\
\hline MT537226/2004 & MN74461 & 19 & $\mathrm{H} 11$ & 1.140 & Present study \\
\hline EF987754/unknown & Unknown & - & $\mathrm{H} 12$ & 1.140 & Koepfli et al. (2008) \\
\hline AB564025/unknown & MC795 & 3 & $\mathrm{H} 12$ & 1.140 & Sato et al. (2012) \\
\hline
\end{tabular}

\section{RESULTS}

Karyotypic analysis of two females (LBCE6437 and LBCE7963) captured in Sumidouro and Teresópolis municipalities at Rio de Janeiro Atlantic Forest, showed $2 n$ $=38$ and $\mathrm{FN}=66$, with a metacentric medium-sized $\mathrm{X}$ chromosome, and a secondary constriction in the largest acrocentric pair (Figure 2). The autosome complement was composed by 15 pairs of biarmed chromosome varying in size from large to small, and three pair of acrocentric chromosomes (Figure 2). 
The $m t$-cytb gene sequences of $32 \mathrm{G}$. cuja samples, 28 herein sequenced showed 13 variable sites and 13 haplotypes. Maximum likelihood analysis showed two well defined lineage, one with $G$. vittata and another with G. cuja (Figure 3), with genetic distance estimates between than more than $12 \%$. In contrast, intraspecific genetic distance estimates within $G$. cuja vary from 0 to $0.44 \%$. MJ network showed a central haplotype $(\mathrm{H} 9)$ directly connected with all other haplotypes, except $\mathrm{H} 4$ (Figure 3).

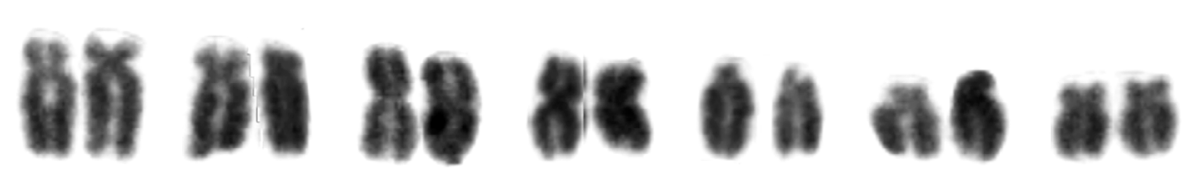 ธa
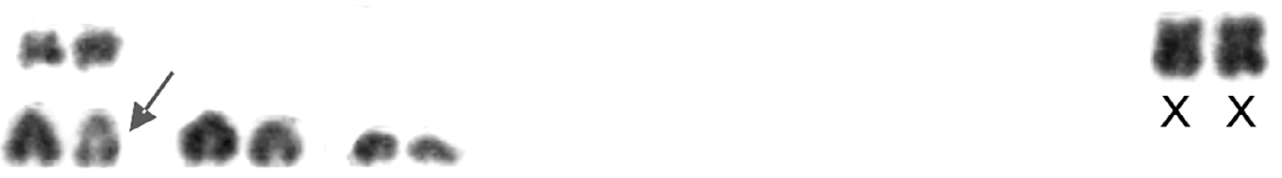

Figure 2. Karyotype with Giemsa staining of a female of Galictis cuja (LBCE7963) from Teresópolis, Rio de Janeiro state, Brazil, with 2n = 38 and $\mathrm{FNa}=66 . \mathrm{X}=$ sexual $\mathrm{X}$ chromosome. The arrow indicates the secondary constriction.

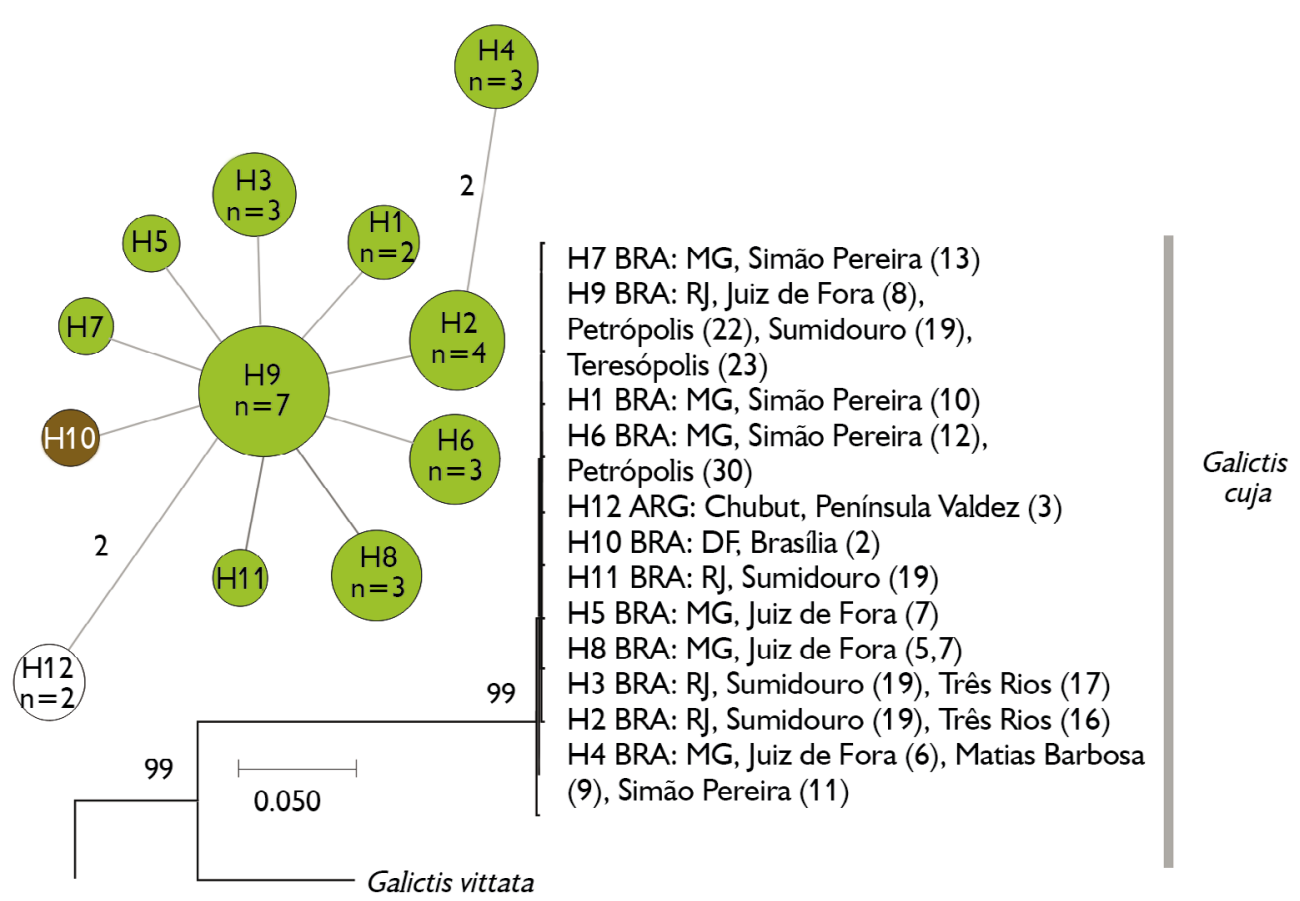

Figure 3. Maximum likelihood (ML, right) topology and median-joining (MJ, left) of Galictis based on mt-Cytb. In ML number near nodes are bootstrap values. In MJ circle size corresponds to number of individuals with a given haplotype, light gray are haplotypes from Atlantic Forest, dark gray from Cerrado, and white from Argentina. Numbers connecting branches denote more than one nucleotide substitutions; connecting branches without a number indicate one nucleotide substitution. Numbers between parentheses refer to localities in the Figure 1.

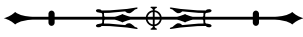




\section{DISCUSSION}

\section{GENETIC CONSIDERATION}

The karyotype of specimens from Rio de Janeiro state, with $2 \mathrm{n}=38$ and $\mathrm{FNa}=66$, recorded in this study, is similar to the single chromosome complement already reported for one male Galictis cuja $(2 \mathrm{n}=38$ and $\mathrm{FN}=$ 68) from Massaranduba in Santa Catarina state (Barbosa, 2013), both karyotypes showing a median sized biarmed $X$ chromosome. The difference in fundamental autosome number is due to a small-sized chromosome. It can be due to different interpretation in relation to the centromere position, or a pericentric inversion affecting this pair. The karyotype herein describes for $G$. cuja confirm the diploid number of 38 as widespread in both genera and species of the order Carnivora, as in Lontra longicaudis (Olfers, 1818) (Freitas et al., 1982), Martes itatsi Temminck, 1844 (Kurose et al., 2000), and Ptenoruna brasiliensis (Gmelin, 1788) (Franco-de-Sá et al., 2007), but differing in the morphology of autosome and sexual chromosomes.

The phylogenetic analysis confirms previous publication in showing Galictis with two lineages. Galictis cuja showed high haplotypic diversity (0.9021) and a low nucleotidic diversity (only 13 variable sites) suggesting that this population expanded after a period of small population size (Su et al., 2015). Even sample from the same locality showed high haplotypic diversity (i.e., Juiz de Fora with 3 haplotypes in 6 sequences; Sumidouro, with 4 haplotypes in 6 sequences). However, specimens collected in the same fragments and different years shared the same haplotype (e.g., LBCE7949, LBCE7956, LBCE7963, LBCE7969 from Teresópolis, haplotype H9; LBCE6587 and LBCE6619 from Sumidouro, haplotype H19; Table 1, Figure 3). The network did not show population structure, suggesting connectivity between populations as previously shown for this species using another marker (Bornholdt et al., 2013).

Our data confirm G. cuja as a common roadkilled mammal in Atlantic Forest, similar to the Cerrado, where $G$. cuja was considered the fifth more roadkill mammalian species, corresponding to $6.1 \%$ of roadkilled mammals (Vieira, E., 1996). This high frequency of roadkill G. cuja was well documented (Rosa \& Mauhs, 2004; Casella et al., 2006; Cherem et al., 2007; Coelho et al., 2008; Sousa \& Miranda, 2010; Bueno et al., 2015). Impressive, the roadkill specimens in BR-040 were captured near urban areas with forest patches or in forested areas, but not in crop fields (Figure 1).

Traditionally Galictis vittata is considered as an inhabitant of humid forests from northern South America to Central America, whereas Galictis cuja is considered as an inhabitant of open areas in southern South America (Rodrigues et al., 2015). However, our data showed that G. cuja could be common in the areas of Atlantic Forest. The fossil records showed that these two species already occurred in Lagoa Santa in the Brazilian Cerrado biome (Rodrigues et al., 2015). The most recent map with the geographic distribution of Galictis cuja places its northmost localities in northeastern Brazil, in the Caatinga biome, and in the Federal District, in the Cerrado of central Brazil (Bornholdt et al., 2013). However, in the Pleistocene deposits, this species also was recorded for the north Cerrado, at Aurora do Tocantins municipality, Tocantins state (Rodrigues et al., 2015; Figure 1). These data showed that the extant southern South America distribution of $G$. cuja, and the northern South America distribution of $G$. vittata could have been moulded modulated by climate change (Rodrigues et al., 2015), together with the current anthropogenic induced range contraction.

\section{ZOONOTIC IMPLICATIONS}

Part of the $G$. cuja roadkill specimens herein analyzed (Appendix 1) was previously investigated for helminth parasitism by Corrêa et al. (2016), and was detected nematodes [Molineus elegans (Travassos, 1921), Dioctophyme renale (Goeze, 1782)], acanthocephalan [Pachysentis gethi (Machado-Filho, 1950)], and digenetic [Platynosomum illiciens (Braum, 1901)], showing the possible role of these animals as a spreader of parasites with zoonotic potential, particularly

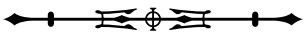


to domestic carnivores, as dogs and cats. Other populations of $G$. cuja from South and Southeastern Brazil were also reported with parasites (Pesenti et al., 2012; Vieira, F. et al., 2017). Furthermore, a Canine Distemper virus has also been reported in a free-ranging G. cuja (Megid et al., 2013). These authors argue that the CDV found in G. cuja and other wild carnivores have resulted from a spillover transmission from domestic dogs, potential reservoirs of this pathogen. The area where the majority of Galictis species were collected is intensively populated, and the contact between G. cuja specimens and dogs in the rural area should be intense. This scenario, plus the connectivity between $G$. cuja populations suggested this mustelid can play a role in the maintenance or even the amplification of the transmission cycle of this pathogen, and that dogs non vaccinated with distemper vaccine can be a threat for $G$. cuja conservation.

\section{CONCLUSION}

Our data confirm that $G$. cuja is a common inhabitant of Atlantic Forest of southeastern Brazil, being a frequent roadkill mammal, similar to the Cerrado region. The karyotype of specimens from Rio de Janeiro state, with $2 \mathrm{n}$ $=38$ and $\mathrm{FNa}=66$, is similar to the single chromosome complement already reported for one male Galictis cuja $(2 \mathrm{n}=38$ and $\mathrm{FNa}=68)$ from Massaranduba in Santa Catarina state (Barbosa, 2013), being the difference in FN due to a small-sized chromosome pair. The phylogenetic analysis showed Galictis cuja with high haplotypic diversity and a low nucleotidic diversity, confirming that this population expanded after a period of small population size. The network did not show population structure, suggesting connectivity between populations as previously showed for this species.

\section{ACKNOWLEDGMENT}

We thank the Laboratório de Biologia e Parasitologia de Mamiferos Reservatórios Silvestres field team for supporting fieldwork, to Vânia de Araujo Soares for collecting roadkill specimen from Distrito Federal, to Concer for support to
Caminhos da Fauna Project, to Rayque Lanes for helping with maps. Work supported by grants to CR Bonvicino (CNPq 304498/2014-9, and FAPERJ E26/201.200/2017, in Instituto Oswaldo Cruz). We are grateful to Riccardo Castiglia and one unknown reviewer for their valuable suggestions and comments in a previous version of this manuscript.

\section{REFERENCES}

ANDRADE, A. F. B. \& C. R. BONVICINO, 2003. A new karyologic variant of Oecomys (Rodentia: Sigmodontinae) and its phylogenetic relationship based on molecular data. Genome 46(2): 195-203. DOI: https://doi.org/10.1139/g02-123

BANDELT, H. J., P. FORSTER \& A. RÖHL, 1999. Median-joining networks for inferring intraspecific phylogenies. Molecular Biology and Evolution 16(1): 37-48. DOI: https://doi.org/10.1093/oxfordjournals. molbev.a026036

BARBOSA, L. T., 2013. Contribuições citogenéticas nas espécies Galictis cuja (Carnivora, Mustelidae) e Scapteromys (Rodentia, Cricetidae). Master Dissertation - Universidade Federal do Paraná, Curitiba.

BARROS, D. M., M. L. LORINI \& V. G. PERSSON, 1990. Dioctophymosis in the Little Grison (Galictis cuja). Journal of Wildlife Diseases 26(4): 538-539. DOI: https://doi.org/10.7589/0090-355826.4.538

BORNHOLDT, R., K. HELGEN, K.-P. KOEPFLI, L. OLIVEIRA, M. LUCHERINI \& E. EIZIRIK, 2013. Taxonomic revision of the genus Galictis (Carnivora: Mustelidae): species delimitation, morphological diagnosis, and refined mapping of geographical distribution. Zoological Journal of the Linnean Society 167(3): 449-472. DOI: https://doi. org/10.1111/.j.1096-3642.2012.00859.x

BUENO, C., C. O. M. SOUSA \& S. R. FREITAS, 2015. Habitat or matrix: which is more relevant to predict roadkill of vertebrates? Brazilian Journal of Biology 75(4), suppl. 1: S228-S238. DOI: http:// dx.doi.org/10.1590/1519-6984.12614

CASELLA, J., N. C. CÁCERES, C. SANTOS GOULART, A. C. PARANHOS FILHO \& P. N. S. CONCEIÇÃO, 2006. Uso de sensoriamento remoto e análise espacial na interpretação de atropelamentos de fauna entre Campo Grande e Aquidauana, MS. Simpósio de Geotecnologias no Pantanal 1: 321-326.

CASSENS, I., S. VICARIO, V. G. WADDELL, H. BALCHOWSKY, D. VAN BELLE, W. DING, C. FAN, R. S. MOHAN, P. C. SIMÕES-LOPES, R. BASTIDA, A. MEYER, M. J. STANHOPE \& MILINKOVITCH, 2000. Independent adaptation to riverine habitats allowed survival of ancient lineages. Proceedings of the National Academy of Sciences 97(21): 11343-11347. DOI: https://doi.org/10.1073/pnas.97.21.11343 
CHEREM, J. J., K. M. AMMERS, I. R. GHIZONI-JR. \&A. MARTINS, 2007. Mamíferos de médio e grande porte atropelados em rodovias do Estado de Santa Catarina, sul do Brasil. Revista Biotemas 20(3): 81-96.

COELHO, I. P., A. KINDEL \& A. V. P. COELHO, 2008. Roadkills of vertebrate species on two highways through the Atlantic Forest Biosphere Reserve, southern Brazil. European Journal of Wildlife Research 54: 689-699. DOI: https://doi.org/10.1007/s10344-0080197-4

CORRÊA, P., C. BUENO, F. M. VIEIRA \& L. C. MUNIZ-PEREIRA, 2016. Helminth parasites of Galictis cuja (Carnivora, Mustelidae), from localities in the Atlantic Forest of Brazil. Brazilian Journal of Parasitology 25(4): 407-413. DOI: https://doi.org/10.1590/s198429612016077

EIZIRIK, E., W. J. MURPHY, K.-P. KOEPFLI, W. E. JOHNSON, J. W. DRAGOO, R. WAYNE \& S. J. O'BRIEN, 2010. Pattern and timing of diversification of the mammalian order Carnivora inferred from multiple nuclear gene sequences. Molecular Phylogenetics and Evolution 56(1): 49-63. DOI: https://doi.org/10.1016/j. ympev.2010.01.033

FERRIOLLI, F. \& M. P. BARRETTO, 1969. Disease reservoirs and wild vectors of Trypanosoma cruzi. Natural infection of the ferret Galictis cuja furax (Thomas, 1907) caused by T. cruzi. Revista do Instituto de Medicina Tropical de São Paulo 11: 264-273.

FLUXUS, [s. d.]. Available at: https://www.fluxus-engineering.com/ about.htm. Accessed on: December 2019.

FLYNN, J. J. \& M. A. NEDBAL, 1998. Phylogeny of the Carnivora (Mammalia): congruence vs incompatibility among multiple data sets. Molecular Phylogenetics and Evolution 9(3): 414-426. DOI: http:// dx.doi.org/10.1006/mpev.1998.0504

FLYNN, J. J., J. A. FINARELLI, S. ZEHR, J. HSU \& M. A. NEDBAL, 2005. Molecular phylogeny of the Carnivora (Mammalia): assessing the impact of increased sampling on resolving enigmatic relationships. Systematics Biology 54(2): 317-337. DOI: http:// dx.doi.org/10.1080/10635150590923326

FRANCO-DE-SÁ, J. F. O., F. C. W. ROSAS \& E. FELDBERG, 2007. Cytogenetic study of the giant otter Pteronura brasiliensis Zimmermann 1780 (Carnivora, Mustelidae, Lutrinae). Genetics and Molecular Biology 30(4): 1093-1096. DOI: http://dx.doi. org/10.1590/S1415-47572007000600011

FREITAS, T. R. O., M. S. MATTEVI \& L. F. B. OLIVEIRA, 1982. Karyotype characterization of lontra (Lutra longicaudis longicaudis, Mustelidae, Carnivora). Mammalian Chromosomes Newsletter 23(3): 91-96

KOEPFLI, K. P. \& R. K. WAYNE, 2003. Type I STS markers are more informative than cytochrome $b$ in phylogenetic reconstruction of the Mustelidae (Mammalia: Carnivora). Systematic Biology 52(2003): 571-593. DOI: http://dx.doi.org/10.1080/10635150390235368
KOEPFLI, K. P., M. E. GOMPPER, E. EIZIRIK, C. C. HO, L. LINDEN, J. E. MALDONADO \& R. K. WAYNE, 2007. Phylogeny of the Procyonidae (Mammalia: Carnivora): molecules, morphology and the great American interchange. Molecular Phylogenetics and Evolution 43(3): 1076-1095. DOI: http://dx.doi.org/10.1016/j. ympev.2006.10.003

KOEPFLI, K.-P., A. A. DEERE, G. J. SLATER, C. BEGG, K. BEGG, L. GRASSMAN, M. LUCHERINI, G. VERON \& R. K. WAYNE, 2008. Multigene phylogeny of the Mustelidae: resolving relationships, tempo and biogeographic history of a mammalian adaptive radiation. BMC Biology 6: 10. DOI: https://doi.org/10.1186/1741-7007-6-10

KUROSE, N., R. MASUDA, T. AOR \& S. WATANABE, 2000. Karyological differentiation between two closely related mustelids, the Japanese weasel Mustela itatsi and the Siberian weasel Mustela siberica. Caryologia 53(3-4): 269-275. DOI: https://doi.org/10.1080 /00087114.2000.10589205

LEDJE, C. \& U. ARNASON, 1996. Phylogenetic analyses of complete cytochrome $b$ genes of the order Carnivora with particular emphasis on the Caniformia. Journal of Molecular Evolution 42: 135-144. DOI: https://doi.org/10.1007/BF02198839

LEVAN, A., K. FREDGA \& A. A. SANDBERG, 1964. Nomenclature for centromeric position on chromosomes. Hereditas 52(2): 201-220. DOI: https://doi.org/10.1111/j.1601-5223.1964.tb01953.x

MEGID, J., C. R. TEIXEIRA, A. CORTEZ, M. B. HEINEMANN, J. M. A. P.ANTUNES, F. FORNAZARI, F. B. RASSY \& L. J. RICHTZENHAIN, 2013. Canine distemper virus infection in a lesser grison (Galictis cuja): first report and virus phylogeny. Pesquisa Veterinária Brasileira 33(2): 247-250. Available at: http://hdl.handle.net/11449/13376. Accessed on: December 2019.

MELO, L. A., 2008. Detecção de Leishmania sp. em pequenos mamíferos silvestres e sinantrópicos no município de Belo Horizonte, MG. Master Dissertation - Fundação Oswaldo Cruz, Belo Horizonte.

PESENTI, T. C., C. S. MASCARENHAS, C. KRÜGER, A. L. SINKOC, A. P. N. ALBANO, M. A. A. COIMBRA \& G. MÜLLER, 2012. Dioctophyma renale (Goeze, 1782) collet-meygret, 1802 (Dioctophymatidae) in Galictis cuja (Molina, 1782) (Mustelidae) in Rio Grande Sul, Brazil. Neotropical Helminthology 6(2): 301-305.

RODRIGUES, S., L. AVILLA \& S. A. K. AZEVEDO, 2015. Diversity and paleoenviromental significance of Brazilian fossil Galictis (Carnivora: Mustelidae). Historical Biology, an International Journal of Paleobiology 28(7): 907-912. DOI: https://doi.org/10.1080/0891 2963.2015.1055559

ROSA, A. O. \&J. MAUHS, 2004. Atropelamento de animais silvestres na rodovia RS-040. Caderno de Pesquisa, Série Biologia 16(1): 35-42.

SAMBROOK, J., E. F. FRITSCH \& T. MANIATIS, 1989. Molecular cloning: a laboratory manual. Cold Spring Harbor Laboratory Press, Cold Spring Harbor, NY.

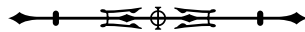


SATO, J. J., M. WOLSAN, F. J. PREVOSTI, G. D'ELÍA, C. BEGG, K. BEGG, T. HOSODA, K. L. CAMPBELL \& H. SUZUKI, 2012. Evolutionary and biogeographic history of weasel-like carnivorans (Musteloidea). Molecular Phylogenetics and Evolution 63(3): 745757. DOI: https://doi.org/10.1016/j.ympev.2012.02.025

SOUSA, M. A. N. \& P. C. MIRANDA, 2010. Mamíferos terrestres encontrados atropelados na rodovia BR-230/pb entre Campina Grande e João Pessoa. BIOFAR - Revista de Biologia e Farmácia 4: $72-82$.

SU, L.-N., X.-C. LI, H.-Z. MENG, X.-Y. GAO, H. YIN \& K. LI, 2015. Population genetic structure and historical demography of the ground beetle Chlaenius costiger in the Tsinling-Dabashan Mountains of central China. Genetics and Molecular Research 14(2): 35793589. DOI: https://doi.org/10.4238/2015.April.17.7

TAMURA, K., G. STECHER, D. PETERSON, A. FILIPSKI \& S. KUMAR, 2013. MEGA6: Molecular Evolutionary Genetics Analysis version 6.0. Molecular Biology and Evolution 30(12): 2725-2729. DOI: https://doi.org/10.1093/molbev/mst197

TORRES-CASTRO, M. A., R. A. MEDINA-PINTO, H. R. NOHPECH, F. I. PUERTO \& R. I. RODRÍGUEZ-VIVAS, 2019. Molecular identification of Toxoplasma gondii in roadkill wild animals in Yucatan, Mexico. Veterinaria Mexico OA 6(1). DOI: https://doi.org/10.22201/ fmvz.24486760e.2019.1.511

TREMORI, T. M., 2018. Identificação criminal de espécies da fauna silvestre por DNA mitocondrial. Doctoral Dissertation Universidade Estadual Paulista, Botucatu.
VIEIRA, E. M., 1996. Highway mortality of mammals in central Brazil. Ciência e Cultura 48(4): 270-272.

VIEIRA, F., L. C. MUNIZ-PEREIRA, S. SOUZA LIMA, A. H. A. MORAES NETO, P. R. GONCALVES \& J. L. LUQUE, 2012. Crenosoma brasiliense sp. n. (Nematoda: Metastrongyloidea) parasitic in lesser grison, Galictis cuja (Molina, 1782) (Carnivora, Mustelidae) from Brazil, with a key to species of Crenosoma Molin, 1861. Folia Parasitologica 59(3): 187-194. DOI: https://doi.org/10.14411/ fp. 2012.026

VIEIRA, F. M., L. C. MUNIZ-PEREIRA, S. SOUZA-LIMA, B. M. ROCHA \&J. L. LUQUE, 2017. Parasitic nematodes of three species of wild carnivore mammals from Atlantic forest in the state of Minas Gerais, Brazil. Revista Mexicana de Biodiversidad 88(4): 801-806. DOI: https://doi.org/10.1016/j.rmb.2017.10.033

WOLSAN, M. \& J. J. SATO, 2010. Effects of data incompleteness on the relative performance of parsimony and Bayesian approaches in a supermatrix phylogenetic reconstruction of Mustelidae and Procyonidae (Carnivora). Cladistics 26(2): 168-194. DOI: https:// doi.org/10.1111/j.1096-0031.2009.00281.x

ZABOTT, M. V., S. B. PINTO, A. M. VIOTT, R. A. TOSTES, L. H. F. B. BITTENCOURT, A. L. KONELL \& L. GRUCHOUSKEI, 2012. Ocorrência de Dioctophyma renale em Galictis cuja. Pesquisa Veterinária Brasileira 32(8): 786-788. DOI: https://doi.org/10.1590/ S0100-736X2012000800018 
Appendix 1. List of samples of Galictis cuja. Voucher numbers are between parentheses. Numbers in square brackets refers to localities in Figure 1. Asterisk $(*)=$ specimens investigated for parasites in previous publication (Corrêa et al., 2016), $\left({ }^{(}\right)=$specimens used in molecular analysis.

ARGENTINA

No locality (EF987754, no voucher); Chubut, [3] Peninsula Valdez -24.5000, -64.0000 (AB564025, voucher MC795).

BRAZIL

Distrito Federal: [2] Brasília, -15.7833, -47.9167 (CRB3283).

Minas Gerais state: Juiz de Fora, [4] BR-040 km 775, -21.6608, -43.4342 (MN79510), [5] BR-040 km 779-783, -21.6917, -43.4483 (MN79153, CB1013, MN83597P), [6] BR-040 km 789, -21.7697, -43.4372 (MN79358*.P), [7] BR-040 km 796-797, -21.8111, -43.3906 (CB1012P), [8] BR-040 km 798, -21.8172, -43.3842 (MN79471*,P), Matias Barbosa, -21.8658, -43.3669 (MN79445*,P), [9] BR-040 km 796 (MN79363P), BR-040 km 805 (CB991P), km 807 (MN79162*); Simão Pereira, [10] BR-040 km 816 -21.9239, -43.3194 (MN79404*.P), [11] BR-040 km 823, -21.9747, -43.2853 (MN79407*.P), [12] BR-040 km 825, -21.9908, -43.2847 (CB1089P), [13] BR-040 km 827, -22.0022, -43.2767 (MN83564*,P, MN79190*).

Rio de Janeiro state: Areal, [20] BR-040 km 42 (MN79314*); Cachoeiras de Macacu, [26] RJ-122 km 25, -22.4667, -42.6500 [26] km 25 (CB1321); Comendador Levy Gasparian, -22.0097, -43.2642 [14] BR-040 km 1-4 (MN79213, CB1237), [15] BR-040 km 10 (MN79154); Duque de Caxias, [31] BR-040 km 97, -22.5833, -43.2606 (MN79452), [32] BR-040 km 100-102, -22.5925, -43.2800 (MN79326*, MN69904), [33] BR-040 km 103, -22.6175, -43.2864 (MN79379*), [34] BR-040 km 106, -22.6442, -43.2836 (MN79421*); Guapimirim, -22.5298, -42.9788, [29] RJ-122 km 10-17 (CB1320, CB1310); Petrópolis, [21] BR-040 km 53, -22.3428, -43.1328 (CB1185', MN79216*), [22] BR040 km 54, -22.3772, -43.1303 (MN79261*), [24] BR-040 km 67, -22.4361, -43.1747 (MN79308), [25] BR-040 km 69, -22.4428, -43.1914 (MN79443*), [27] BR-040 km 77, -22.4931, -43.2231 (MN79334), [28] km 78, -22.4997, -43.2292 (MN83573), [30] BR-040 km 71, -22.5631, -43.2314 (MN79501*.P, MN83244, MN79550P); Sumidouro, [19] -22.0504, -42.6842 (MN74461 $\left.{ }^{\mathrm{P}}\right)$, Bairro da Volta (LBCE7780 $)$, Piedade (LBCE6587 $)$, Soledade (LBCE6619P), Vale do Encanto (LBCE5276P, LBCE6437P), Vale do Pamparrão (LBCE7241P); Teresópolis, [23] -22.4241, -42.9680 (LBCE7949P, LBCE7956P, LBCE7963P, LBCE7969P); Três Rios, [16] BR-040 km 11, -22.0469, -43.2006 (MN79247*,P), [17] BR-040 km 14, -22.0681, -43.1942 (MN79294*,P), [18] BR-040 km 15, -22.0744, -43.1892 (MN79436, CB1294). Tocantins state: [1] Aurora do Tocantins, -12.7121, -46.4072 (fossil specimen, Rodrigues et al., 2015).

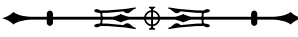

